\title{
Mixed Model Cipp Dan Kickpatrick Sebagai Pendekatan Evaluasi Program Pengembangan Kompetensi Guru Berbasis Kebutuhan Peningkatan Kemampuan Asessement Literasi-Numerasi (Cilapp Model Dalam Evaluasi Program)
}

\author{
Yetti Supriyati $^{1}$, Muqorobin ${ }^{2}$ \\ Universitas Negeri Jakarta ${ }^{1}$ Program Penelitian \& Evaluasi Pendidikan PPs Universitas Negeri \\ Jakarta $^{2}$ \\ Email: roobin41@ymail.com
}

\begin{abstract}
Abstrak: Pengembangan kompetensi guru berbasis kebutuhan untuk peningkatan kemampuan asessemen literasi-numerasi saat merupakan menjadi kebutuhan bagi sekolah dalam upaya peningkatan mutu dan sikap adaptif sekolah. Terdapat berbagai strategi untuk pemenuhan kebutuhan pengembangan kompetensi guru, salah satunya melakukan pelatihan dan pembinaan guru secara berkelanjutan. Penelitian ini merupakan bentuk kajian literatur yang mengelaobrasi dan menganalisis berbagai penelitian pengembangan komptensi guru terdahulu dengan berbagai pendekatan. Di landasi keyakinan bahwa keberhasilan dan efektifitas pelaksanaan program pengembangan perlu dilakukan evaluasi dan kajian ilmiah yang mendalam baik dari aspek konteks, input, program pengembangan, proses dan produk. Model evaluasi CIPP dan Kickpatrick dinilai sebagai pendekatan yang komplementer dalam pelaksanaan evaluasi program. Berdasarkan hasil penelitian dapat disimpulkan bahwa dengan kedua model tersebut diproyeksikan dapat memberikan deskripsi secara utuh dalam pengkajian dan penelitian secara mendalam tentang pelaksanaan program pengembangan kompetensi guru. Dengan kedua model tersebut juga dapat didapatkan rekomendasi secara komprehensif dan saling melengkapi dalam kelangsungan program.
\end{abstract}

Kata kunci: CIPP, Kickpatrick, Pengembangan Kompetensi Guru, Kemampuan Asessment

\section{PENDAHULUAN}

Mencermati data laporan hasil Ujian Nasional SMA tahun 2019 yang dirilis Puspendik menunjukkan bahwa rerata nilai seluruh mata pelajaran secara nasional masih rendah. Pencapaian rerata pada program studi IPA meliputi; rerata mata pelajaran Bahasa Indonesia 69.69, rerata mata pelajaran Bahasa Inggris 53.58, rerata mata pelajaran Matematika 39.33, rerata mata pelajaran Fisika 46.47, rerata mata pelajaran Kimia 50.99 dan rerata mata pelajaran Biologi 50.61. Sedangkan, rerata pada program studi IPS meliputi; rerata mata pelajaran Bahasa Indonesia 59.52, rerata mata pelajaran Bahasa Inggris 44.78, rerata mata pelajaran Matematika 39.46, rerata mata pelajaran Ekonomi 52.39, rerata mata pelajaran Sosiologi 51.98 dan rerata mata pelajaran Geografi 50.59 (puspendik.kemdikbud.go.id).

Selanjutnya, berdasarkan laporan dari hasil studi Programme for International Student Assessment (PISA) 2018 telah dirilis pada hari Selasa, 3 Desember 2019. Berdasarkan hasil studi tersebut Peringkat PISA Indonesia Tahun 2018 Turun apabila dibandingkan dengan Hasil PISA tahun 2015. Studi pada tahun 2018 ini menilai 600.000 anak berusia 15 tahun dari 79 negara setiap tiga tahun sekali. Studi ini membandingkan kemampuan matematika, membaca, dan kinerja sains dari tiap anak. Pada kategori kemampuan membaca, Indonesia berada pada peringkat 74. Skor rata-rata Indonesia adalah 371, berada di bawah Panama yang memiliki skor rata-rata 377 . Sedangkan, pada kategori matematika, Indonesia berada di peringkat 73 dengan skor rata-rata 379 . Indonesia berada di atas Arab Saudi yang memiliki skor rata-rata 373 (kemdikbud.go.id).

Terakhir, berdasarkan laporan Bank Dunia yang dirilis pada bulan Agustus 2020 menunnukkan skor kemampuan membaca siswa Indonesia dalam Programme for International Student Assessment (PISA) diproyeksikan menurun sebagai dampak dari 
pandemi Covid-19. Bank Dunia membagi skenario menjadi tiga, yaitu skenario saat ini (4 bulan), skenario optimis (6 bulan), dan skenario pesimis ( 6 bulan). Pada skenario saat ini, siswa Indonesia kehilangan 11 poin kemampuan membaca. Sementara skenario optimis kehilangan 16 poin dan pesimis kehilangan hingga 21 poin. (World Bank, 1 Agustus 2020).

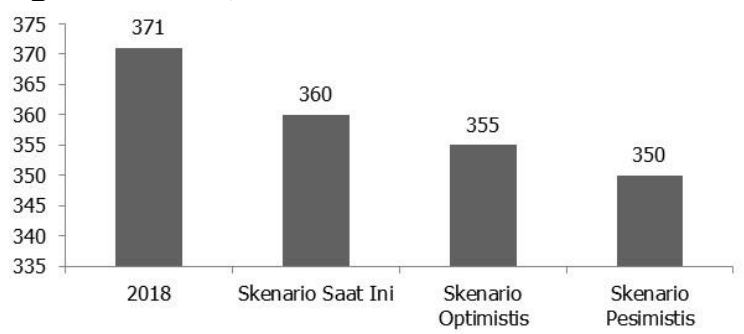

Gambar 1. Grafik tren skor PISA akibat Covid 19.

Menyadari kondisi tersebut, maka dibutuhkan upaya penyelesaian untuk perbaikan pencapaian tujuan pendidikan. Salah satunya melalui peningkatan kompetensi guru. Dalam implementasinya guru memiliki peran penting, seperti melalui program pengembangan keprofesian berkelanjutan (PKB) bagi guru diharapkan dapat meningkatkan pencapaian kualitas lulusan peserta didik yang berdaya saing dengan berbekal kemampuan literasi dan numerasi.

Terkait dengan konteks itu, saat ini pemerintah telah menunjukkan upaya perbaikan pada tata kelola profesionalisme guru di era revolusi industri 4.0 guna mendorong percepatan pencapaian tujuan pendidikan nasional. Komitmen pemerintah dalam upaya perbaikan kualitas pendidikan ditunjukkan dengan adanya pergeseran kebijakan yaitu proporsi peningkatan kompetensi guru melalui Pengembangan Keprofesian Berkelanjutan sebesar (PKB) $30 \%$ dengan merujuk pada Permendiknas No. 16 Tahun 2007 tentang Standar Kompetensi Guru dan peningkatan kompetensi lulusan peserta didik melalui Peningkatan Kompetensi Pembelajaran (PKP) sebesar 70\% dengan merujuk pada Permendikbud No. 20, 21, 22, 23, 24 Tahun 2016 No. 35, 36, 37 tahun 2018 Kurikulum 2013.
Esensi dari pergeseran kebijakan program peningkatan kompetensi pembelajaran adalah untuk mendorong peran guru agar lebih optimal dalam meningkatkan kualitas proses pembelajaran dan penilaian yang berorientasi pada pengembangan literasi dan numerasi serta penguasaan materi yang berbasis HOTS. Oleh karena itu, guru harus memiliki kemampuan dalam menyesuaikan dengan perkembangan dunia pendidikan dan melakukan inovasi pembelajaran dengan meningkatkan kompetensi nya.

Terkait dengan hal itu, data yang dirilis surat kabar Pikiran Rakyat mengemukakan beberapa fakta yang menjadi potret pendidikan kita, yaitu: (1) Nilai rata-rata kemampuan calon guru dalam menjawab soal uji kompetensi ketika dilakukan test calon guru masih menunjukkan kemampuan penguasaan bidang kompetensi yang masih kurang.Kemampuan rata-rata calon guru berdasarkan kemampuan menjawab soal uji kompetensi ketika melakukan test calon guru masih menunjukkan nilai rata-rata di bawah $50 \%$, yaitu hanya sebesar $44 \%$. Kemampuan terendah ditunjukkan pada kompetensi fisika dan matematika sebesar $33 \%$ dan $46 \%$. Sementara, kemampuan tertinggi ditunjukkan pada kompetensi bahasa inggris sebesar 58\%. Hal ini menunjukkan masih rendahnya kompetensi para calon guru di Indonesia. (2) Kompetensi pedagogik, menunjukkan pencapaian nilai rata-rata pada uji kompetensi guru pada tahun 2015 sebesar 56.69\%; (3) Berdasarkan lulusan perguruan tinggi, menunjukkan kualitas berbeda, tetapi tidak begitu signifikan berdasarkan hasil UKG tahun 2015; (Pikiran Rakyat, 2016).

Berdasarkan data tersebut, menunjukkan bahwa data kualitas kompetensi guru maupu data indeks pembangunan manusia maupun, Indonesia masih tertinggal jauh jika dibandingkan dengan Negara-negara tetangga di kawasan Asean. Untuk itu, berbagai kebijakan pembangunan manusia Indonesia dalam upaya meningkatkan daya saing bangsa melalui pendidikan perlu dilakukan. peningkatan kompetensi guru dalam penguasaan dan pelaksananan asessement berbasis literasi dan numerasi perlu 
dilakukan, tujuannya untuk meningkatkan mutu pendidikan Nasional.

Berbagai pendekatan program pengembangan kompetensi untuk meningkatkan kualitas pendidikan sudah dilakukan, diantaranya: Pelatihan-pelatihan guru, perubahan kurikulum, program-program kemitraan, meningkatkan dan melakukan perubahan kurikulum, program kemitraan, peningkatan pendidikan guru dan dosen, serta berbagai program lainnya (Agung Prihantoro, 2012:93).

Dengan mengacu pada beberapa data dan deskripsi di atas, meskipun pemerintah sudah melakukan berbagai upaya alternatif untuk program pelatihan dan pengembangan, akan tetapi program pengembangan kometnsi tersebut masih belum diikuti dengan peningkatan kemapuan hasil pendidikan pada peserta didik sebagaimana ditunjukkan datadata pada data laporan PISA, rata-rata hasil UN dan hasil asesmen kompetensi siswa yang sudah dilakukan oleh Pusat Penilaian Pendidikan Kemendikbud pada tahun 2019. Dengan demikian, dapat disimpulkan bahwa pengelolaan program-program pengembangan kompetensi guru belum dilakukan secara efektif dan belum berdampak secara signifikan dalam peningkatan kemampuan peserta didik terutama pada aspek literasi dan numerasi. Program pengembangan kompetensi guru perlu dilakukan evaluasi agar terwujud peningkatan kompetensi dan perubahan mutu hasil pendidikan sesuai kebutuhan.

Terdapat beberapa model dan pendekatan yang digunakan dalam mengevaluasi pelaksanaan program pengembangan komponen kompetensi guru. Dalam penelitian ini akan dideskripsikan secara konseptual tentang model evaluasi yang digunakan, kompetensi guru dan kemampuan asessement literasi-numerasi.

Evaluasi adalah proses aktifitas untuk mengumpulkan informasi tentang sesuatu obyek masalah, selanjutnya informasi tersebut digunakan untuk menentukan rekomendasi dan alternatif yang tepat dalam mengambil sebuah keputusan (Arikunto, 2009). Berdasarkan deskripsi di atas dapat kita pahami bahwa evaluasi adalah menyediakan informasi yang dapat dijadikan pertimbangan untuk menentukan alternatif yang tepat dalam mengambil sebuah keputusan dari dampak sebuah proyek, program dan kebijakan

Stufflebeam \& Shinkfield mendefinisikan Evaluation is the process of delineating, obtaining, and providing descriptive and judgmental information about the worth and merit of some object's goals, desgn, implementation, and impact in order to guide decision making, serve needs for accountability, and promote understanding of the involved phenomena.

Kufman and Thomas (1980:4) menyatakan bahwa evaluasi adalah proses yang digunakan untuk menilai. Hal senada dikemukakan oleh Djaali, Mulyono dan Ramly (2002:3) mendefinisikan evaluasi dapat diartikan sebagai proses menilai sesuatu berdasarkan kriteria atau standar objektif yang dievaluasi.

Selanjutnya Sanders sebagai ketua The Joint Committee on Standars for Educational Evaluation (1994) mendefinisikan evaluasi sebagai kegiatan investigasi yang sistimatis tentang kebenaran atau keberhasilan suatu tujuan. Evaluasi program menurut Joint Commite yang dikutip oleh Brinkerhoff (1986:xv) adalah aktivitas investigasi yang sistematis tentang sesuatu yang berharga dan bernilai dari suatu obyek. Pendapat lain Denzin and Lincoln (2000:983), mengatakan bahwa evaluasi program berorientasi sekitar perhatian dari penentu kebijakan dari penyandang dana secara karakteristik memasukkan pertanyaan penyebab tentang tingkat terhadap mana program telah mencapai tujuan yang diinginkan. Di dalam evaluasi terdapat berbagai model yang dijadikan suatu pendekatan.

Model Evaluasi CIPP dirancang oleh Daniel L. Stufflebeam (1985). Tujuan model evaluasi ini adalah berorientasi kepada pemegang keputusan (a decision oriented evaluation approach structured) untuk menolong pihak-pihak tertentu membuat keputusan. Menurut Stufflebeam model evaluasi ini merupakan sebagai suatu proses yang menggambarkan, memperoleh dan 
menyediakan informasi yang berguna untuk menilai alternatif keputusan.

Dalam model evaluasi CIPP terdapat empat bagian evaluasi yang fungsinya sebagai pedoman kerja dalam menghadapi masalah pendidikan. Berikut adalah uraian tentang model evaluasi CIPP menurut Wirawan (2008); 1) Evaluasi Konteks (Context Evaluation); 2) Evaluasi Masukan (Input Evaluation); 3) Evaluasi Proses (Process Evaluation); 4) Evaluasi Produk (Product Evaluation). Evaluasi ini dilaksanakan untuk mengukur kuantitas dan kualitas hasil pelaksanaan program. Hasil ini dibandingkan dengan obyektif dari program serta dipergunakan untuk mengambil keputusan apakah program diteruskan, dihentikan atau dirubah.

Kirkpatrick salah seorang ahli evaluasi program pelatihan dalam bidang pengembangan sumber daya manusia (SDM). Model evaluasi yang dikembangkan oleh Kirkpatrick dikenal dengan istilah Kirkpatrick Four Levels Evaluation Model. Evaluasi terhadap efektivitas program pelatihan (training) menurut Kirkpatrick (1998) mencakup empat level evaluasi, yaitu: level 1 reaction, level 2 learning, level 3 behavior, dan level 4 result.

Evaluasi terhadap reaksi peserta pelatihan/program berarti mengukur kepuasan peserta (customer satisfaction). Program pelatihan dianggap efektif apabila proses pelatihan dirasa menyenangkan dan memuaskan bagi peserta pelatihan sehingga mereka tertarik termotivasi untuk belajar dan berlatih.

Kirkpatrick (1998) mengemukakan "learning can be defined as the extend to which participans change attitudes, improving knowledge, and/or increase skill as a result of attending the program". Berdasarkan pendapat tersebut terdapat tiga hal yang dapat instruktur ajarkan dalam program pelatihan, yaitu pengetahuan, sikap maupun keterampilan.

Kriteria keberhasilan pada evaluasi level ke 3 adalah perubahan sikap yang telah terjadi setelah mengikuti pelatihan akan diimplementasikan setelah mahasiswa mengikuti perkuliahan, sehingga penilaian tingkah laku ini lebih bersifat eksternal. Evaluasi hasil dalam level ke 4 ini difokuskan pada hasil akhir yang terjadi karena peserta telah mengikuti suatu program. Dalam kegiatan pembelajaran model evaluasi ini mengarah pada hasil akhir yang diperoleh mahasiswa.

Dalam konteks penelitian ini, level model evaluasi Kirkpatric yang dikombinasikan adalah level learning atau training. Pengambilan level training karena dalam pelaksanaan program peningkatan mutu penilaian hasil belajar terdapat program pengembangan kompetensi guru melalui berbagai bentuk pelatihan.

Guru sebagai profesi tentunya perlu memenuhi kompetensi yang telah dipersyaratkan oleh pemerintah melalui undang-undang Dosen dan Guru Nomor: 14 Tahun 2005. Oleh karena itu, dalam upaya mendukung melaksanakan profesi guru sebagai jabatan profesional, maka perlu senantiasa kompetensi guru untuk terus dikembangkan.

Pelaksanaan program pengembangan dimulai dari kegiatan persiapan, kemudian menyajikan dan memberikan kesempatan untuk mencoba. Pada pelaksanaan program harus dilakukan dengan disiplin yang tinggi baik fasilitator atau instruktur maupun peserta program pengembangan. Para peserta dan fasilitator harus memiliki ketaatan pada jadwal yang telah ditentukan merupakan salah satu indikator suksesnya kegiatan program pengembangan.

Dalam pelaksanaan program pengembangan adalah penting untuk mempertimbangkan lingkungan kerja, sehingga proses transfer pengetahuan dan keterampilan peserta program pengembangan efektif untuk dilaksanakan pada kondisi nyata di pekerjaan.

Menurut Wukir (2012:73-76) dalam upaya pengembangan kompetensi guru terdapat berbagai program yang dapat dilakukan, diantaranya adalah: In service training, seminar, program induksi, on the job training, off the job training, vestibule 
training, sensitivity training dan supplementary Training.

In service training for teacher secara umum adalah upaya meningkatkan kemampuan guru-guru dengan berbagai jenis pelatihan, sehingga diharapkan guru-guru dapat meningkatkan kualifikasi dan kompetensinya sehingga berdampak terhadap kualitas sekolah. Secara umum, seminar merupakan bentuk dari instruksi akademik, baik yang dibuat oleh institusi akademik maupun oleh organisasi profesional. Dimana seminar ini dapat membantu pengembangan keprofesionalan guru-guru dengan meningkatkan pengetahuan guru-guru. Sementara, induction bertujuan untuk mengenalkan karyawan atau guru-guru baru pada pekerjaan dan lingkungan kerja mereka yang baru.

On The Job Training, adalah suatu bentuk pengembangan yang dapat mempercepat proses pemindahan atau transfer pengetahuan dan pengalaman kerja dari karyawan senior ke karyawan junior. Metode yang digunakan dalam on the job training dimana karyawan atau guru mempelajari suatu keahlian dengan mengamati atau melakukan observasi terhadap karyawan lain yang sedang bekerja dengan keahlian tersebut. Sementara, of the job training merupakan bentuk pelatihan dan pengembangan yang dilakukan di luar lingkungan kerja. Biasanya dilakukan secara khusus di rung tertentu dimana peserta mendapatkan pengetahuan secara teoritis tentang pekerjaan tertentu.

Vestibule training merupakan sebuah prosedur yang digunakan dalam pelatihan dimana lokasi pelatihan terpisah dari area produktif utama. Jenis ini hampir mirip dengan On The Job Training, dimana peserta diberikan pelatihan mengenai bahan dan jenis alat yang akan digunakan di lingkungan pekerjaan. Kursus Penyegaran merupakan jenis pelatihan dan pengembangan dengan tujuan untuk memperbaharui pengetahuan dan keahlian karyawan. Sementara, sensitivity training merupakan jenis pelatihan dan pengembangan dengan tujuan untuk mengembangkan kesadaran dalam pola perilaku karyawan dan biasanya untuk mendorong pemahaman bersama di dalam kelompok kerja.

Asessesment (penilaian) adalah proses memilih, mengumpulkan, dan menafsirkan informasi untuk membuat keputusan atau untuk membuat penilaian tentang kelemahan suatu produk atau program, atau tentang sejauh mana keberhasilan pendekatan yang telah dilakukan dapat menyelesaikan masalah sehingga dapat menyempurnakan suatu sasaran/tujuan.

Kemampuan guru dalam melakukan asessement atau penilaian dapat dideskripsikan dengan beberapa tahap kegiatan. Pertama, guru harus mampu merumuskan tujuan evaluasi yang akan dilaksanakan dengan jelas, apabila tujuan evaluasi belajar tidak dirumuskan dengan jelas maka akan evaluasi berjalan tanpa arah dan mengakibatkan kehilangan arti dan fungsi dari evaluasi tersebut. Kedua, guru harus mampu menetapkan aspek yang akan dievaluasi, perlu di ingat bahwa evaluasi belajar berdasarkan kompetensi bukan hanya mengacu pada ranah kognitif saja, melainkan juga pada ranah afektif dan psikomotorik.

Ketiga, guru harus mampu memilih dan menentukan teknik yang akan digunakan dalam pelaksanaan evaluasi, misalnya apakah evaluasi itu akan dilaksanakan dengan teknik tes atau non tes, jika teknik yang digunakan non tes, apakah pelaksanaan non tes menggunakan observasi, wawancara atau angket. Keempat, guru mampu menyusun alat-alat pengukuran, seperti butir-butir soal tes, check list, rating scale, wawancara atau questionnaire. Kelima, guru harus mampu menentukan tolak ukur atau kriteria yang akan dijadikan pegangan atau patokan dalam memberikan interpretasi terhadap data hasil evaluasi. Misalnya apakah guru akan menggunakan penilaian beracuan patokan (PAP) atau menggunakan penilaian beracuan kelompok atau normal (PAN).

Literasi merupakan salah satu prasyarat kecakapan hidup di abad ke-21. World Economic Forum, pada tahun 2015 telah menyepakati enam literasi dasar, diantaranya; literasi baca tulis, literasi numerasi, literasi 
sains, literasi digital, literasi finansial, dan literasi budaya dan kewargaan (Ibrahim, 2017:5). Keenam literasi tersebut tidak hanya penting bagi peserta didik saja, tetapi juga orang tua dan semua masyarakat. Salah satu literasi yang memiliki peran terkait pengambilan keputusan dalam kehidupan sehari-hari adalah literasi numerasi. Sementara kemampuan literasi numerasi di Indonesia belum berkembang.

Berdasarkan uraian di atas literasi sangatlah penting untuk dikembangkan guna menyiapkan generasi pada abad ke-21. Literasi sebagai salah satu wujud penumbuhan budi pekerti melalui pembudayaan yang menjadi karakter. Melihat pada kenyataan bahwa tingkat numerasi Negara Indonesia sangatlah rendah, maka literasi numerasi memiliki peran penting dalam pembudayaan melalui kegiatan seharihari.

Sedangkan, numerasi dapat diartikan sebagai kemampuan untuk mengaplikasikan konsep bilangan dan keterampilan operasi hitung di dalam kehidupan sehari-hari (misalnya, di rumah, pekerjaan, dan partisipasi dalam kehidupan masyarakat dan sebagai warga negara) dan kemampuan untuk menginterpretasi informasi kuantitatif yang terdapat di sekeliling kita. Kemampuan ini ditunjukkan dengan kenyamanan terhadap bilangan dan cakap menggunakan keterampilan matematika secara praktis untuk memenuhi tuntutan kehidupan. Kemampuan ini juga merujuk pada apresiasi dan pemahaman informasi yang dinyatakan secara matematis, misalnya grafik, bagan, dan tabel (Kemdikbud, 2021).

Numerasi digagas oleh World Economic Forum atau OECD, pada tahun 2006, UNESCO menyampaikan bahwa numerasi dapat menjadi salah satu penentu kemajuan suatu bangsa. Matematika dan numerasi memiliki perbedaan yang terletak pada pemberdayaan pengetahuan dan keterampilan. Pembelajaran matematika belum tentu menumbuhkan numerasi, tetapi dalam melaksanakan numerasi diperlukan pengetahuan matematika yang diperoleh melalui pembelajaran dalam kurikulum.

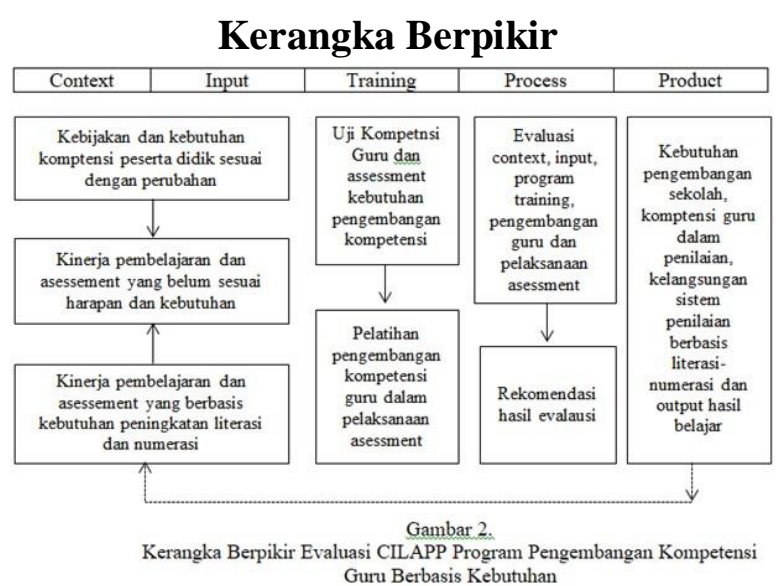

Berdasarkan pada gambar di atas dapat dideskripsikan bahwa program pengembangan kompetensi guru berbasis kebutuhan mengacu pada konteks kebutuhan dan input yang didapatkan melalui kajian pendahuluan. Selanjutnya untuk memperkuat program pengembangan dilakukan pelatihan sebagai bentuk treatment untuk penguatan dari pengembangan kometensi guru secara berkelanjutan. Kemudian pada inti program pengembangan adalah pelaksanaan dari program tersebut dengan mengacu pada konteks, input dan pelatihan. Terakhir, untuk mengetahui efektifitas dari pelaksanaan program maka dilakukan pengkajian terhadap produk dari program yang benbentuk output dan outcome.

\section{Metodologi Penelitian}

Jenis penelitian ini adalah kajian literatur (literature review). Yudi Agusta (2007) mengatakan Literature Review is a critical analysis of the research conducted on a particular topic or question in the field of science yang artinya Literature Review merupakan analisa kritis dari penelitian yang sedang dilakukan terhadap topik khusus atau berupa pertanyaan terhadap suatu bagian dari keilmuan. Literature Review dapat membantu dalam menyusun kerangka berfikir yang sesuai dengan teori, temuan, maupun hasil penelitian sebelumnya dalam menyelesaikan rumusan masalah pada penelitian yang dibuat.

Sifat dari penelitian kepustakaan ini adalah analisis deskriptif, yakni penguraian secara teratur data yang telah diperoleh, kemudian diberikan pemahaman dan penjelasan agar dapat dipahami dengan baik 
oleh pembaca. Adapun prosedur pencarian artikel melalui google search, google scholar, science direct, Erick dan schimago dengan merujuk pada tema penelitian, CIPP, Kickpatrick, kometensi guru dan kemampuan asessemen serta literasi-numerasi. Cakupan tahun terbit jurnal adalah 2010 - 2020 .

Berikut ini data alamat www.google.co.id/?hl=id,

www.sciencedirect.com/ scholar.google.co.id, eric.ed.gov/, dan www.scimagojr.com/.

Artikel yang dimuat dalam jurnal sesuai dengan kriteria konteks penelitan yang kemudian diambil untuk dilakukan ianalisis. Bentuk artikel yang direview merujuk kepada artikel yang dapat diakses fulltext dalam format pdf dan scholarly (peer reviewed journals). Kriteria jurnal yang direview adalah artikel jurnal penelitian dengan berbahasa Indonesia dan bahsa inggris yang melakukan kajian tentang kompetensi guru, kemampuan asessement dan literasi-numerasi dengan model CIPP dan Kickpatrick.

Jurnal yang sesuai dengan kriteria inklusi dan terdapat tema tentang efektifitas pelaksanaan program pengembangan komtensi guru melalui CIPP. Selain itu juga artikel dala jurnal yang mengakaji tentang learning atau training bagi guru sebagai bagian dalam program pengembangan. Kritera inklusi penelitian dapat dilihat pada tabel berikut ini:

Tabel 1.Kriteria Inklusi Peneltian

\begin{tabular}{|l|l|}
\hline \multicolumn{1}{|c|}{ Kriteria } & \multicolumn{1}{c|}{ Inklusi } \\
\hline $\begin{array}{l}\text { Jangka } \\
\text { waktu }\end{array}$ & Jurnal tahun \\
\hline subjek & $\begin{array}{l}\text { Model Evaluasi CIPP dan } \\
\text { Kirpartick }\end{array}$ \\
\hline bahasa & $\begin{array}{l}\text { Bahasa Indonesia dan } \\
\text { bahasa Inggris }\end{array}$ \\
\hline Jenis Jurnal & Artikel penelitian, full text \\
\hline Tema isi & $\begin{array}{l}\text { Evaluasi program } \\
\text { pengembangan kompetensi } \\
\text { guru, kemampuan } \\
\text { asessesment literasi- } \\
\text { numerasi dengan Model } \\
\text { CIPP dan Kickpatrict }\end{array}$ \\
\hline
\end{tabular}

Jurnal penelitian yang sesuai dengan kriteria inklusi kemudian dikumpulkan dan dibuat ringkasan jurnal meliputi nama peneliti, tahun terbit jurnal, judul penelitian, metode dan ringkasan hasil atau temuan. Ringkasan jurnal penelitian tersebut dimasukan ke dalam tabel sesuai dengan format tersebut di atas.abel 2.

Ringkasan Jurnal

\begin{tabular}{|c|c|c|}
\hline Judul Artikel & $\begin{array}{c}\text { Tahun } \\
\text { Terbit }\end{array}$ & $\begin{array}{c}\text { Ringkasan Hasil } \\
\text { Temuan }\end{array}$ \\
\hline $\begin{array}{l}\text { Upaya } \\
\text { Meningkatkan } \\
\text { Kompetensi } \\
\text { Guru dalam } \\
\text { Melaksanakan } \\
\text { Penilaian } \\
\text { Kurikulum } 2013 \\
\text { melalui } \\
\text { Bimbingan } \\
\text { Terstruktur di } \\
\text { MIN 2 } \\
\text { Gunungkidul. } \\
\text { Susianti. Artikel } \\
\text { dalam Jurnal } \\
\text { Pendidikan } \\
\text { Madrasah, } \\
\text { Volume 3, } \\
\text { Nomor 1, Mei } \\
\text { 2018 P-ISSN: } \\
\text { 2527-4287 - E- } \\
\text { ISSN: 2527- } \\
\text { 6794 }\end{array}$ & Mei 2018 & $\begin{array}{l}\text { This research } \\
\text { aims to improve } \\
\text { the ability of } \\
\text { teachers as an } \\
\text { effort in carrying } \\
\text { out the } \\
\text { assessment based } \\
\text { on the curriculum } \\
\text { at MIN } \\
\text { Gunungkidul } \\
\text { through structured } \\
\text { guidance. The } \\
\text { subject } \\
\text { research is the } \\
\text { teachers } \\
\text { Gunungkidul } \\
\text { MIN } 2 \text { years of } \\
\text { 2017/2018 Lesson } \\
8 \text { persons consist } \\
\text { of } 2 \text { teachers are } \\
\text { male and } 6 \text { female } \\
\text { teachers. } \\
\text { research } \\
\text { conducted in three } \\
\text { cycles. Research } \\
\text { data obtained } \\
\text { through } \\
\text { observation } \\
\text { assessment } \\
\text { administration } \\
\text { and observation } \\
\text { classes. } \\
\text { Assessment based } \\
\text { on the curriculum } \\
\text { on } 2013 \text { cycle I } \\
\text { the ability of } \\
\text { teachers } \\
\text { mastering } \\
\text { techniques } \\
\text { scoring average } \\
\text { value of } 74.56 \text { In } \\
\text { cycle II, the } \\
\text { ability of a } \\
\text { teacher } \\
\text { mastering } \\
\text { techniques } \\
\text { scoring average } \\
84.5 . \text { Cycle III the } \\
\text { ability of teachers }\end{array}$ \\
\hline
\end{tabular}




\begin{tabular}{|c|c|c|}
\hline & & $\begin{array}{l}\text { in mastering } \\
\text { techniques } \\
\text { scoring average } \\
\text { value of } 87.53 \text {. Of } \\
\text { the observations } \\
\text { obtained } \\
\text { improvement } \\
\text { belongs to the } \\
\text { criteria either. } \\
\text { This means that } \\
\text { with structured } \\
\text { guidance method } \\
\text { can be used to } \\
\text { improve the } \\
\text { ability of teachers } \\
\text { in carrying out an } \\
\text { assessment based } \\
\text { on the curriculum } \\
2013 \text { at MIN } 2 \\
\text { Gunungkidul. }\end{array}$ \\
\hline $\begin{array}{l}\text { Peningkatan } \\
\text { Kompetensi } \\
\text { Guru dalam } \\
\text { Menyusun } \\
\text { Rubrik Penilaian } \\
\text { Melalui } \\
\text { Pembinaan } \\
\text { Terstruktur } \\
\text { (Penelitian } \\
\text { Tindakan di } \\
\text { SDN 1 Cempaka } \\
\text { Lampung Utara) } \\
\text { Ernawati. } \\
\text { Artikel dalam } \\
\text { jurnal Pedagogia } \\
\text { | ISSN Online : } \\
\text { 2715-6125 }\end{array}$ & Juli 2018 & $\begin{array}{l}\text { One of the } \\
\text { important tasks of } \\
\text { the teacher is } \\
\text { conducting } \\
\text { research. } \\
\text { research The } \\
\text { developed at this } \\
\text { time is the Class } \\
\text { Research Model. } \\
\text { But the reality on } \\
\text { the ground, the } \\
\text { assessment of } \\
\text { learning outcomes } \\
\text { is still very poorly } \\
\text { adjusted. This is } \\
\text { due to research } \\
\text { conducted by } \\
\text { teachers currently } \\
\text { not using the } \\
\text { assessment rubric. } \\
\text { Therefore, it is } \\
\text { necessary to have } \\
\text { an effort to } \\
\text { improve teacher } \\
\text { competency in } \\
\text { compiling } \\
\text { assessment } \\
\text { rubrics so that } \\
\text { research meets the } \\
\text { expected } \\
\text { requirements. The } \\
\text { problem in this } \\
\text { study is how to } \\
\text { improve the } \\
\text { competence of } \\
\text { teachers in grades } \\
\text { IV, V, VI } \\
\text { teaching } \\
\text { Indonesian North } \\
\text { Lampung }\end{array}$ \\
\hline
\end{tabular}

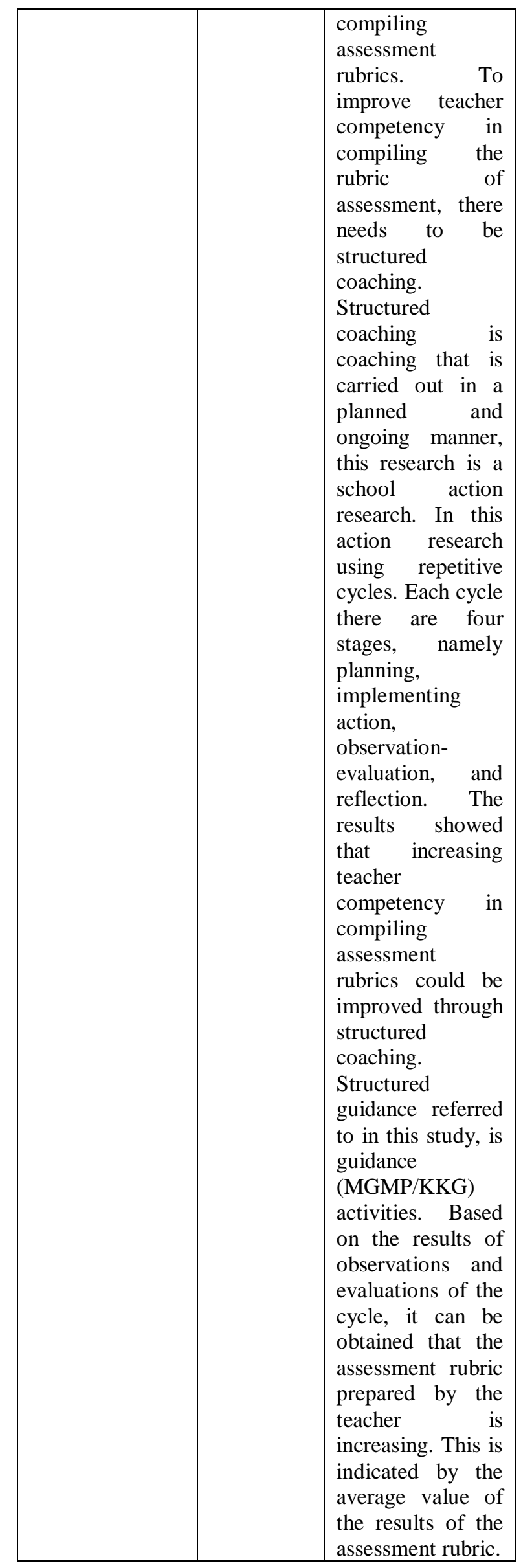




\begin{tabular}{|c|c|c|}
\hline $\begin{array}{l}\text { Kompetensi } \\
\text { Guru Dalam } \\
\text { Penilaian Hasil } \\
\text { Belajar } \\
\text { SMK Bertaraf } \\
\text { Internasional } \\
\text { Edy Supriyadi. } \\
\text { Artikel dalam } \\
\text { jurnal } \\
\text { Pendidikan } \\
\text { Teknik Elektro } \\
\text { FT UNY }\end{array}$ & $\begin{array}{c}\text { Agustus } \\
2012\end{array}$ & 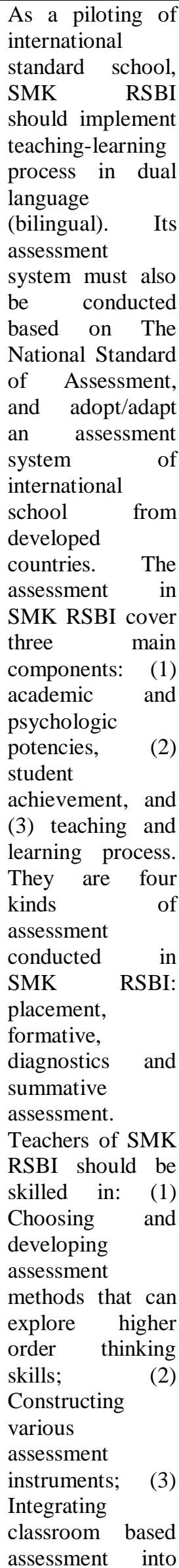 \\
\hline
\end{tabular}

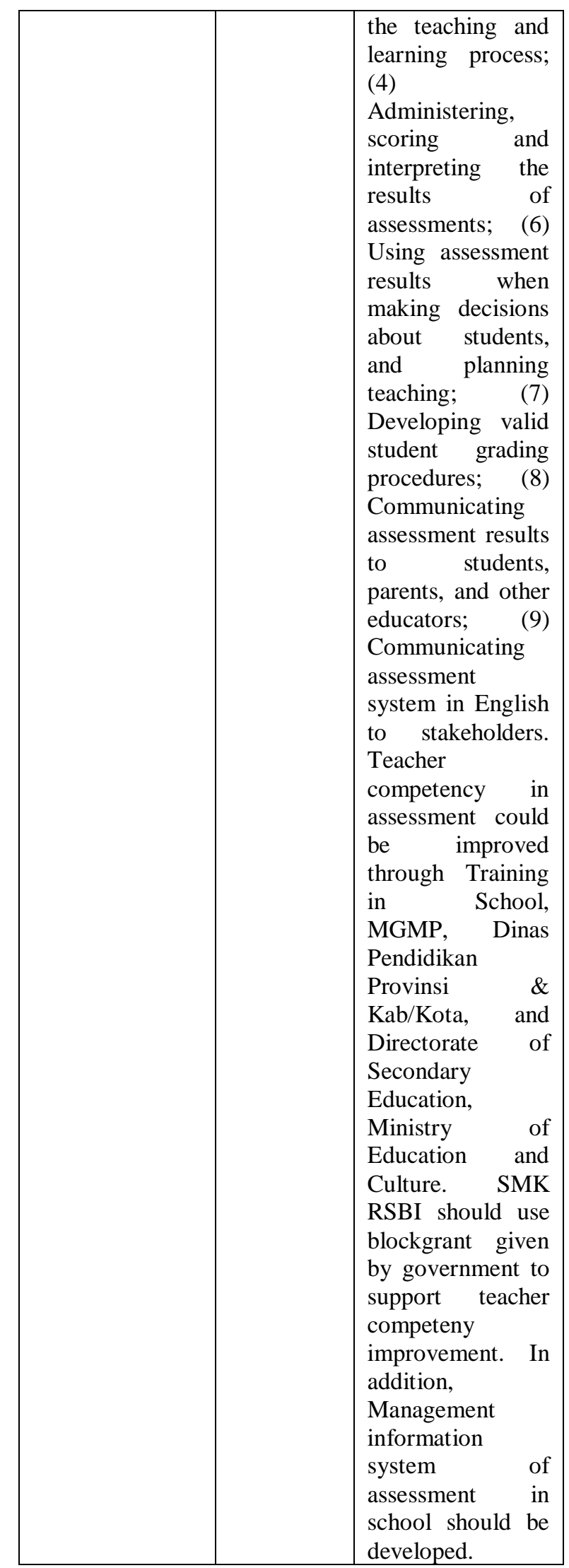




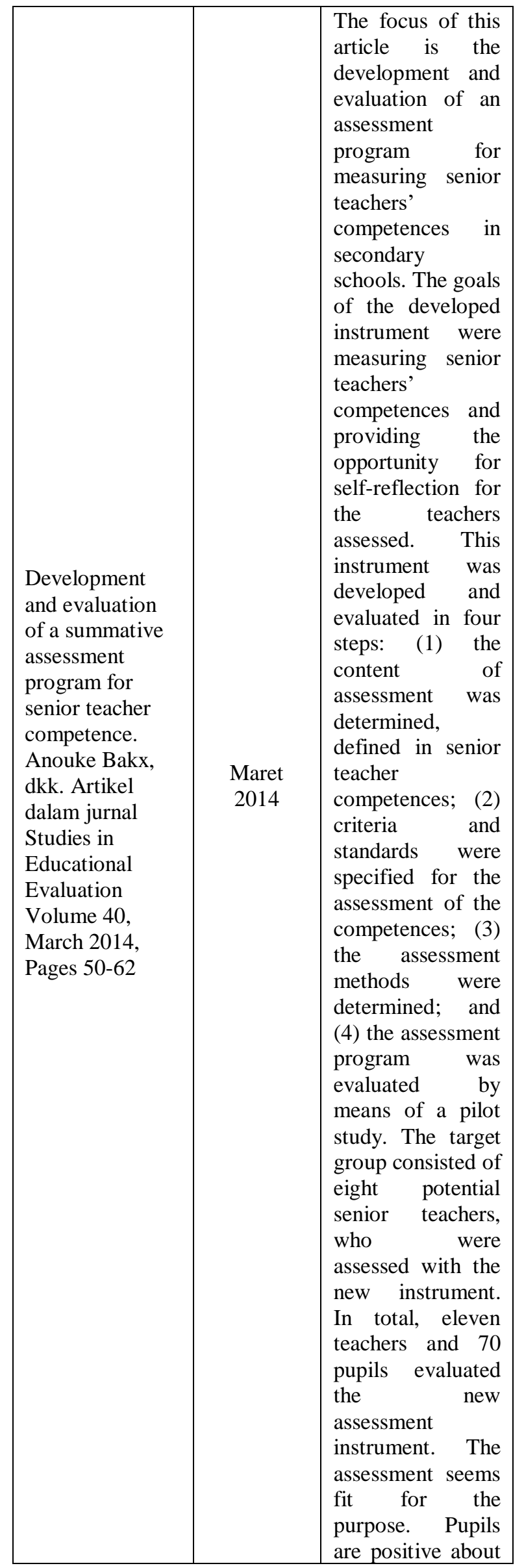

\begin{tabular}{|c|c|c|}
\hline & & $\begin{array}{l}\text { the assessment } \\
\text { program, whereas } \\
\text { the teachers are } \\
\text { more sceptic } \\
\text { about it. }\end{array}$ \\
\hline $\begin{array}{l}\text { Helping teachers } \\
\text { to develop } \\
\text { competence } \\
\text { criteria for } \\
\text { evaluating their } \\
\text { professional } \\
\text { development } \\
\text { Bill Rawson. } \\
\text { Artikel dalam } \\
\text { International } \\
\text { Journal of } \\
\text { Educational } \\
\text { Development } \\
\text { Volume 21, } \\
\text { Issue 2, January } \\
\text { 2001, Pages 79- } \\
92\end{array}$ & $\begin{array}{c}\text { Januari } \\
2001\end{array}$ & 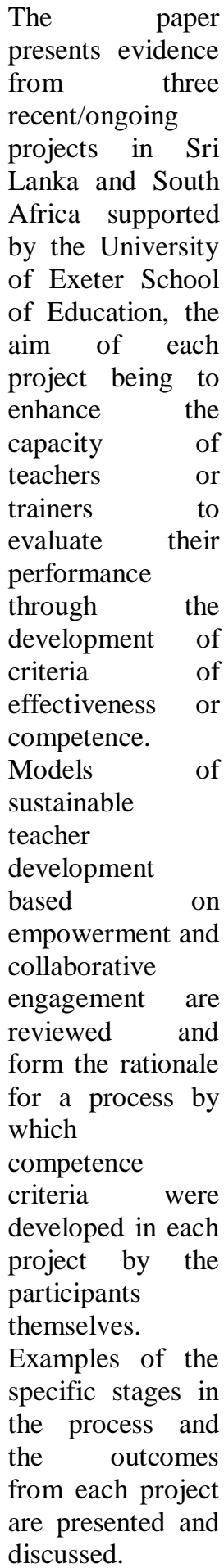 \\
\hline $\begin{array}{l}\text { In pursuit of } \\
\text { beginning } \\
\text { teachers' } \\
\text { competence in } \\
\text { promoting } \\
\text { reading } \\
\text { motivation: A }\end{array}$ & $\begin{array}{c}\text { November } \\
2020\end{array}$ & $\begin{array}{l}\text { As teachers' } \\
\text { reading } \\
\text { motivation and } \\
\text { self-efficacy for } \\
\text { promoting reading } \\
\text { motivation can be } \\
\text { considered vital }\end{array}$ \\
\hline
\end{tabular}




\begin{tabular}{|c|c|c|}
\hline $\begin{array}{l}\text { mixed-methods } \\
\text { study into the } \\
\text { impact of a } \\
\text { continuing } \\
\text { professional } \\
\text { development } \\
\text { program } \\
\text { Iris } \\
\text { Vansteelandt. } \\
\text { Artikel dalam } \\
\text { jurnal Teaching } \\
\text { and Teacher } \\
\text { Education } \\
\text { Volume 96, } \\
\text { November 2020, } \\
\text { 103154 }\end{array}$ & & $\begin{array}{l}\text { for their reading- } \\
\text { oriented } \\
\text { promotive } \\
\text { teaching practices } \\
\text { and students' } \\
\text { reading } \\
\text { motivation, this } \\
\text { study evaluated } \\
\text { the impact of a } \\
\text { year-long CPD } \\
\text { program for } \\
\text { beginning primary } \\
\text { school teachers. A } \\
\text { convergent } \\
\text { parallel mixed- } \\
\text { methods design } \\
\text { with repeated } \\
\text { measures was } \\
\text { established, } \\
\text { including } \\
\text { comparison and } \\
\text { two CPD } \\
\text { conditions (group } \\
\text { vs. individually- } \\
\text { oriented). Based } \\
\text { on the } \\
\text { quantitative } \\
\text { results only no } \\
\text { clear impact of } \\
\text { and differences } \\
\text { between the } \\
\text { conditions could } \\
\text { be observed. The } \\
\text { qualitative } \\
\text { analysis, however, } \\
\text { showed growth in } \\
\text { teachers reading } \\
\text { motivation and } \\
\text { self-efficacy at a } \\
\text { different pace and } \\
\text { level of intensity } \\
\text { for both CPD } \\
\text { conditions. }\end{array}$ \\
\hline $\begin{array}{l}\text { The effects of } \\
\text { teacher } \\
\text { competence on } \\
\text { student } \\
\text { outcomes in } \\
\text { elementary } \\
\text { science } \\
\text { education: The } \\
\text { mediating role of } \\
\text { teaching quality } \\
\text { Jasmin } \\
\text { Decristan, dkk. } \\
\text { Artikel dalam } \\
\text { jurnal Teaching } \\
\text { and Teacher } \\
\text { Education } \\
\text { Volume } 86 \text {, }\end{array}$ & $\begin{array}{c}\text { November } \\
2019\end{array}$ & $\begin{array}{l}\text { In this } \\
\text { contribution, we } \\
\text { investigate links } \\
\text { between teacher } \\
\text { competence, } \\
\text { teaching quality, } \\
\text { and student } \\
\text { outcomes in } \\
\text { elementary } \\
\text { science education. } \\
\text { Students' } \\
\text { conceptual } \\
\text { understanding and } \\
\text { interest were } \\
\text { measured during } \\
\text { two teaching units } \\
\text { in a pre-post }\end{array}$ \\
\hline
\end{tabular}

\begin{tabular}{|c|c|c|}
\hline $\begin{array}{l}\text { November 2019, } \\
102882\end{array}$ & & $\begin{array}{l}\text { design (1070 } \\
\text { students, } 54 \\
\text { classes). Results } \\
\text { show that teacher } \\
\text { competence } \\
\text { (pedagogical } \\
\text { content } \\
\text { knowledge, self- } \\
\text { efficacy, and } \\
\text { teaching } \\
\text { enthusiasm) was } \\
\text { positively related } \\
\text { to students' } \\
\text { interest; self- } \\
\text { efficacy was } \\
\text { positively related } \\
\text { to student } \\
\text { achievement. } \\
\text { Three dimensions } \\
\text { of teaching } \\
\text { quality (cognitive } \\
\text { activation, } \\
\text { supportive } \\
\text { climate, and } \\
\text { classroom } \\
\text { management), } \\
\text { which refer to the } \\
\text { actual teacher- } \\
\text { student- } \\
\text { interactions in the } \\
\text { classroom, } \\
\text { mediated these } \\
\text { relationships. } \\
\text { These results help } \\
\text { illuminate the } \\
\text { mechanisms } \\
\text { behind the effects } \\
\text { of teachers on } \\
\text { student outcomes. }\end{array}$ \\
\hline $\begin{array}{l}\text { Development of } \\
\text { Professional } \\
\text { Teacher } \\
\text { Competences for } \\
\text { Cooperation } \\
\text { with Parents. } \\
\text { Viskovic, Ivana; } \\
\text { Višnjic Jevtic, } \\
\text { Adrijana. 2017. } \\
\text { Artikel dalam } \\
\text { Jurnal Early } \\
\text { Child } \\
\text { Development } \\
\text { and Care, v187 } \\
\text { n10 p1569-1582 } \\
2017\end{array}$ & Juli 2017 & $\begin{array}{l}\text { Based on the } \\
\text { belief that } \\
\text { professional } \\
\text { competences can } \\
\text { partially } \\
\text { developed } \\
\text { through } \\
\text { professional } \\
\text { training a cycle of } \\
\text { ten educational } \\
\text { workshops was } \\
\text { designed. } \\
\text { Combining } \\
\text { theoretical } \\
\text { knowledge, } \\
\text { quality practice } \\
\text { examples and } \\
\text { discussions, the } \\
\text { workshops strived } \\
\text { to improve } \\
\text { professional }\end{array}$ \\
\hline
\end{tabular}




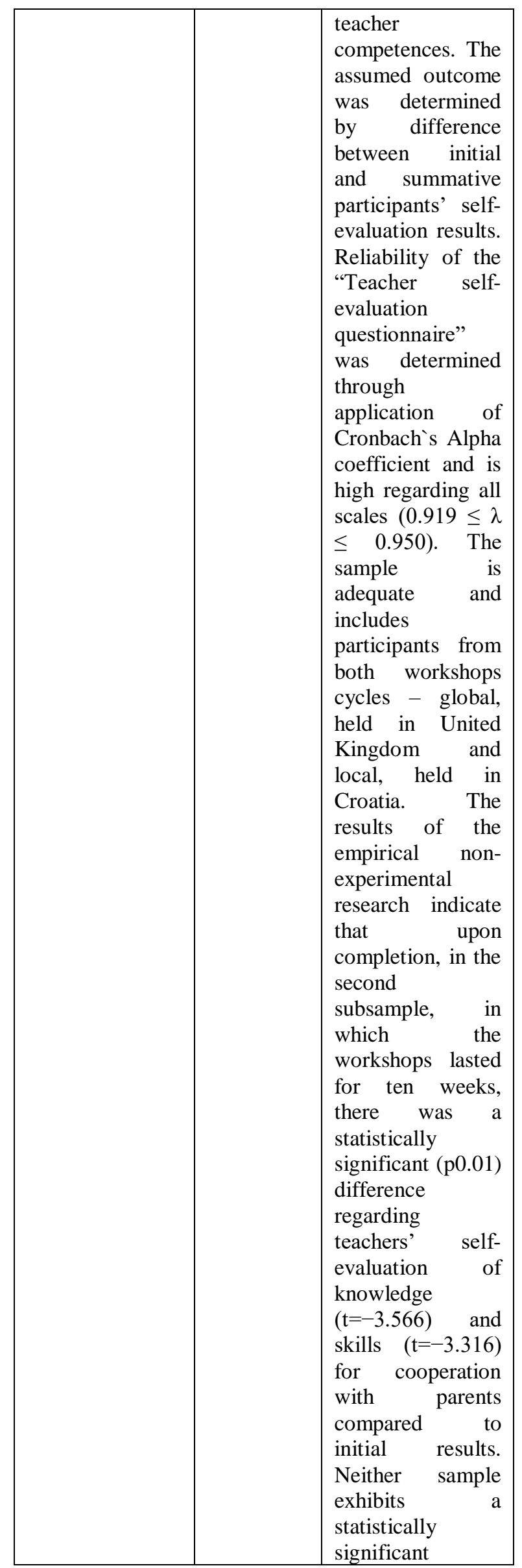

\begin{tabular}{|c|c|c|}
\hline & & $\begin{array}{l}\text { difference } \\
\text { regarding self- } \\
\text { evaluation } \\
\text { attitudes. } \\
\text { Teachers estimate } \\
\text { that they have } \\
\text { developed } \\
\text { knowledge and } \\
\text { skills necessary } \\
\text { for cooperation } \\
\text { with parents by } \\
\text { the systematic } \\
\text { training in a } \\
\text { specific period of } \\
\text { time which allows } \\
\text { for verification } \\
\text { and practice of } \\
\text { learned skills. }\end{array}$ \\
\hline $\begin{array}{l}\text { Peningkatan } \\
\text { Kemampuan } \\
\text { Guru Sekolah } \\
\text { Dasar dalam } \\
\text { Penyusunan } \\
\text { Instrumen Ranah } \\
\text { Sikap Melalui In } \\
\text { House Training. } \\
\text { Astuti, S., } \\
\text { Slameto, S., \& } \\
\text { Dwikurnaningsi } \\
\text { h, Y.. Artikel } \\
\text { dalam Jurnal } \\
\text { Manajemen } \\
\text { Pendidikan, } \\
\text { 4(1), 37-47. } \\
\text { https://doi.org/ht } \\
\text { tps://doi.org/10.2 } \\
\text { 4246/j.jk.2017.v } \\
\text { 4.i1.p37-47 }\end{array}$ & Juni 2027 & $\begin{array}{l}\text { This study departs } \\
\text { from the issues of } \\
\text { teacher skills gaps } \\
\text { in Elementary } \\
\text { School of } \\
\text { Laboratorium } \\
\text { Satya Wacana in } \\
\text { arranging the } \\
\text { instrument of } \\
\text { attitudes } \\
\text { assessment. This } \\
\text { gap problems } \\
\text { would be solved } \\
\text { by school action } \\
\text { research which } \\
\text { aims to determine } \\
\text { the steps of in- } \\
\text { house training } \\
\text { that can improve } \\
\text { teachers' skills in } \\
\text { preparing } \\
\text { attitudes } \\
\text { instrument. The } \\
\text { subjects of this } \\
\text { study involved } 15 \\
\text { primary school } \\
\text { teachers } \\
\text { Elementary } \\
\text { School of } \\
\text { Laboratorium } \\
\text { Satya Wacana. } \\
\text { The research } \\
\text { model that used } \\
\text { was Stringer } \\
\text { Model which } \\
\text { consist of } 3 \\
\text { aspects, namely : } \\
\text { Look, Think, and } \\
\text { Act. Instruments } \\
\text { in this study were } \\
\text { observation sheet } \\
\text { and booklet. The }\end{array}$ \\
\hline
\end{tabular}




\begin{tabular}{|c|c|c|}
\hline & & $\begin{array}{l}\text { data was analyzed } \\
\text { quantitatively and } \\
\text { qualitatively. The } \\
\text { result showed: 1) } \\
\text { The steps of in- } \\
\text { house training } \\
\text { that can improve } \\
\text { teachers, skills } \\
\text { are planning, } \\
\text { implementing, } \\
\text { and evaluating in } \\
\text { house training. On } \\
\text { the steps of } \\
\text { planning, } \\
\text { activities of the } \\
\text { formation of a } \\
\text { committee, } \\
\text { determine the } \\
\text { trainer, } \\
\text { participants, } \\
\text { material and } \\
\text { schedule. During } \\
\text { the the } \\
\text { implementation } \\
\text { phase carried out } \\
\text { activities ranging } \\
\text { from pretest, } \\
\text { delivery and } \\
\text { discussion } \\
\text { materials and } \\
\text { posttest. At this } \\
\text { stage of the } \\
\text { evaluation carried } \\
\text { out assessments } \\
\text { throughout the in } \\
\text { house training } \\
\text { activities; 2) In- } \\
\text { house training can } \\
\text { enhance teachers' } \\
\text { skills in arranging } \\
\text { attitudes } \\
\text { assessments } \\
\text { during learning process. } \\
\text { The contribution } \\
\text { of this research } \\
\text { theoretically } \\
\text { maintains } \\
\text { arranging steps of } \\
\text { Likert assessment } \\
\text { scale practically } \\
\text { improve teachers' } \\
\text { skills in arranging } \\
\text { attitude } \\
\text { assessment } \\
\text { teaching } \\
\text { learning process. }\end{array}$ \\
\hline $\begin{array}{l}\text { Assessing } \\
\text { competency- }\end{array}$ & April 2020 & $\begin{array}{l}\text { The contexts in } \\
\text { which evaluators }\end{array}$ \\
\hline
\end{tabular}

\begin{tabular}{|c|c|}
\hline $\begin{array}{l}\text { based evaluation } \\
\text { course impacts: } \\
\text { A mixed } \\
\text { methods case } \\
\text { study } \\
\text { Cheryl N.Poth } \\
\text { MichelleSearle } \\
\text { Alexandra } \\
\text { M.Aquilina } \\
\text { JennyGe } \\
\text { AlexaElder . } \\
\text { Artikel dalam } \\
\text { jurnal Evaluation } \\
\text { and Program } \\
\text { Planning } \\
\text { Volume 79, } \\
\text { April 2020, } \\
\text { 101789 }\end{array}$ & 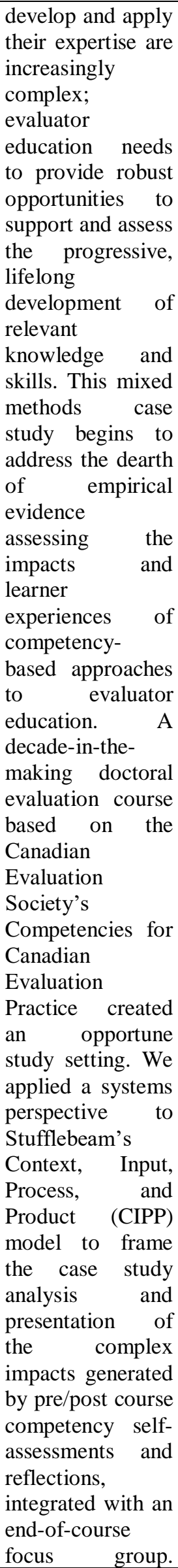 \\
\hline
\end{tabular}




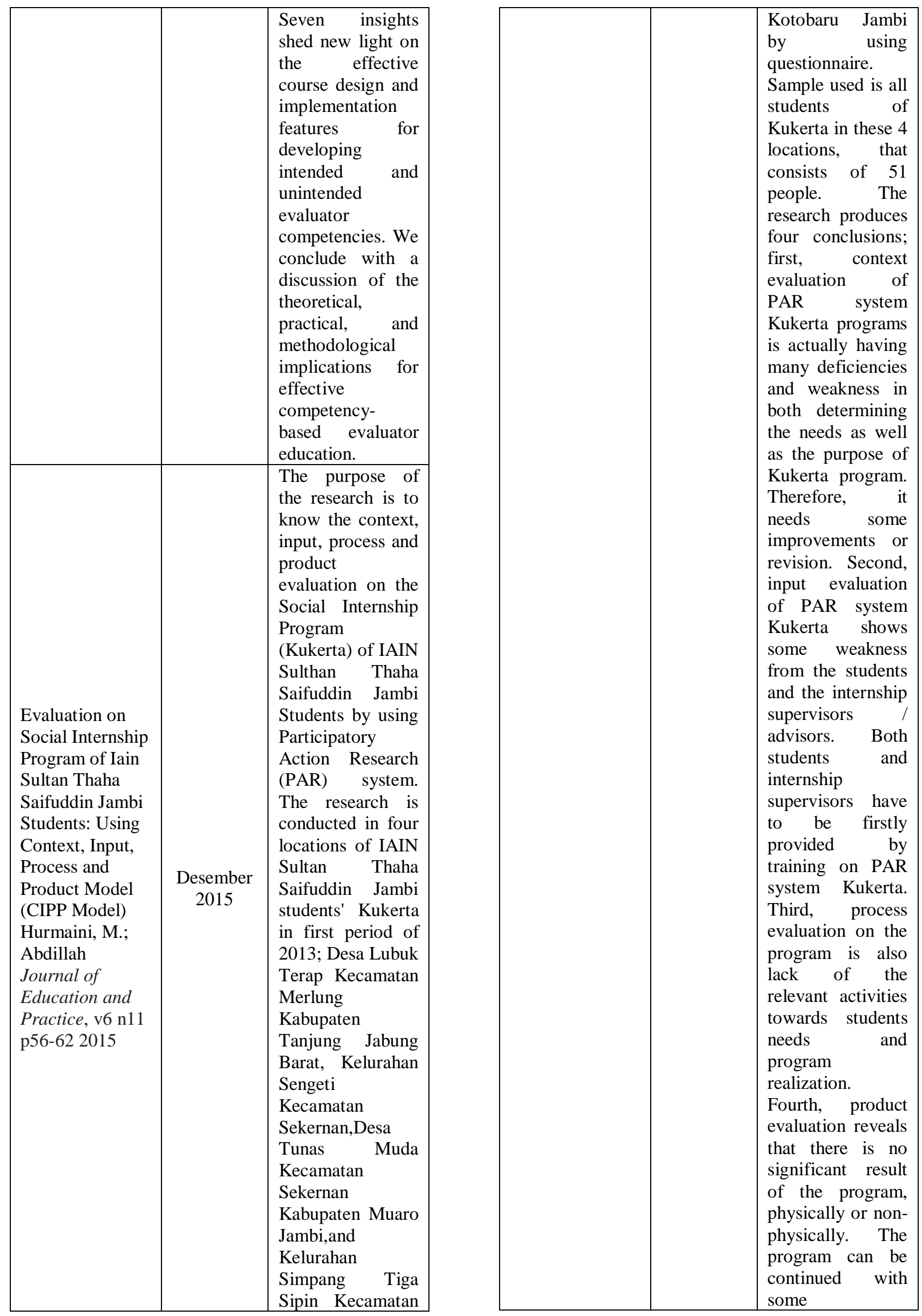




\begin{tabular}{|c|c|c|}
\hline $\begin{array}{l}\text { Implementation } \\
\text { of CIPP Model } \\
\text { for Quality } \\
\text { Evaluation at } \\
\text { School Level: A } \\
\text { Case Study } \\
\text { Shamsa Aziz, } \\
\text { Munazza } \\
\text { Mahmood, } \\
\text { Zahra Rehman. } \\
\text { Artikel dalam } \\
\text { Journal of } \\
\text { Education and } \\
\text { Educational } \\
\text { Developement }\end{array}$ & 2018 & 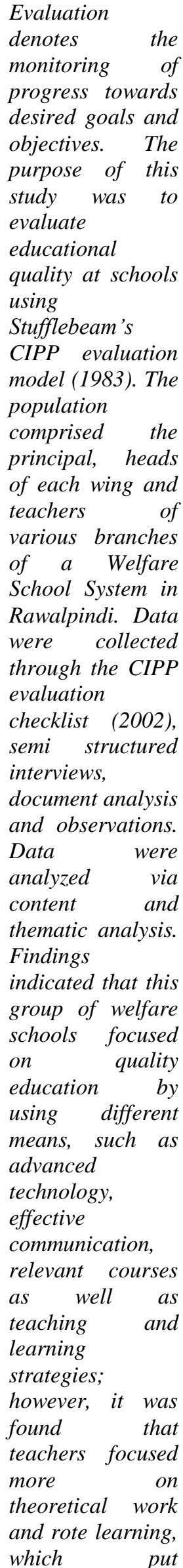 \\
\hline
\end{tabular}




\begin{tabular}{|c|c|c|}
\hline & & $\begin{array}{l}\text { pressure on } \\
\text { students and had } \\
\text { a negative effect } \\
\text { on their } \\
\text { intellectual } \\
\text { abilities. } \\
\text { Moreover, there } \\
\text { was lack of } \\
\text { proper space, } \\
\text { effective and } \\
\text { environment and } \\
\text { the schools were } \\
\text { situated in rented } \\
\text { buildings. }\end{array}$ \\
\hline $\begin{array}{l}\text { Evaluation of } \\
\text { effectiveness of } \\
\text { training and } \\
\text { development: } \\
\text { The Kirkpatrick } \\
\text { model. } \\
\text { Mohammed } \\
\text { Saad, AlYahya } \\
\text { and Mat, } \\
\text { Norsiah. Artikel } \\
\text { dalam Asian } \\
\text { Journal of } \\
\text { Business and } \\
\text { Management } \\
\text { Sciences, } 2 \text { (11). } \\
\text { pp. 14-24. ISSN } \\
\text { 2047-2528 }\end{array}$ & 2013 & $\begin{array}{l}\text { Evaluation of } \\
\text { training } \\
\text { effectiveness is } \\
\text { the measurement } \\
\text { of improvement } \\
\text { in the employee's } \\
\text { knowledge, skill } \\
\text { and behavioral } \\
\text { pattern within the } \\
\text { organization as a } \\
\text { result of training } \\
\text { program. This } \\
\text { measurement help } \\
\text { to match the cost } \\
\text { incurred in the } \\
\text { design and } \\
\text { implementation of } \\
\text { training with the } \\
\text { associated } \\
\text { benefits. Thus, it } \\
\text { indicates whether } \\
\text { the program has } \\
\text { been able to } \\
\text { deliver its } \\
\text { intended goals } \\
\text { and objectives. } \\
\text { The purpose of } \\
\text { this paper is to } \\
\text { review the model } \\
\text { of training } \\
\text { effectiveness for } \\
\text { the adoption by } \\
\text { the human } \\
\text { resources } \\
\text { development } \\
\text { executives in their } \\
\text { planning, } \\
\text { designing and } \\
\text { implementation } \\
\text { training }\end{array}$ \\
\hline $\begin{array}{l}\text { Implementation } \\
\text { Of Kirkpatrick } \\
\text { Model On } \\
\text { Technical } \\
\text { Guidelines For }\end{array}$ & $\begin{array}{c}\text { Desember } \\
2020\end{array}$ & $\begin{array}{l}\text { The research } \\
\text { method uses an } \\
\text { evaluation } \\
\text { developed by } \\
\text { Kirkpactrik. Data }\end{array}$ \\
\hline
\end{tabular}

\begin{tabular}{|c|c|}
\hline $\begin{array}{l}\text { Teacher } \\
\text { Performance } \\
\text { Assessment Of } \\
\text { Basic Education } \\
\text { PerformancE. } \\
\text { Hadi, P., } \\
\text { Wibawa, B., \& } \\
\text { Sukardjo, M. } \\
\text { Artikel dalam } \\
\text { International } \\
\text { Journal of } \\
\text { Education, } \\
\text { Information } \\
\text { Technology, and } \\
\text { Others, 2(2), 55- } \\
\text { 71. } \\
\text { https://doi.org/1 } \\
\text { 0.5281/10.5281/ } \\
\text { zenodo.3598142 }\end{array}$ & $\begin{array}{l}\text { collection } \\
\text { techniques using a } \\
\text { questionnaire. } \\
\text { Data analysis } \\
\text { techniques using } \\
\text { descriptive } \\
\text { analysis. } \\
\text { Participant } \\
\text { research } \\
\text { participants in the } \\
\text { Teacher } \\
\text { Performance } \\
\text { Peenilian } \\
\text { Technical } \\
\text { Guidance in } 2018 . \\
\text { Technical } \\
\text { Guidance } \\
\text { Teacher on } \\
\text { Performance } \\
\text { Evaluation is } \\
\text { carried out with } \\
\text { the aim of } \\
\text { providing teachers } \\
\text { with skills to be } \\
\text { able to use the } \\
\text { Teacher } \\
\text { Performance } \\
\text { Assessment } \\
\text { instrument to their } \\
\text { peers. Evaluations } \\
\text { at each important } \\
\text { level are carried } \\
\text { out to determine } \\
\text { the level of } \\
\text { effectiveness. } \\
\text { Based on the } \\
\text { results of the } \\
\text { study obtained the } \\
\text { following data; } \\
\text { (1) the level of } \\
\text { reaction } \\
\text { participants stated } \\
\text { that } \\
\text { implementation of } \\
\text { Bimtek was very } \\
\text { good; (2) at the } \\
\text { level of learning } \\
\text { participants have } \\
\text { a very good } \\
\text { understanding of } \\
\text { the } \\
\text { Guidance } \\
\text { material. It was } \\
\text { concluded that the } \\
\text { implementation of } \\
\text { the } \\
\text { Performance } \\
\text { Evaluation } \\
\text { Technical } \\
\text { Guidance }\end{array}$ \\
\hline
\end{tabular}




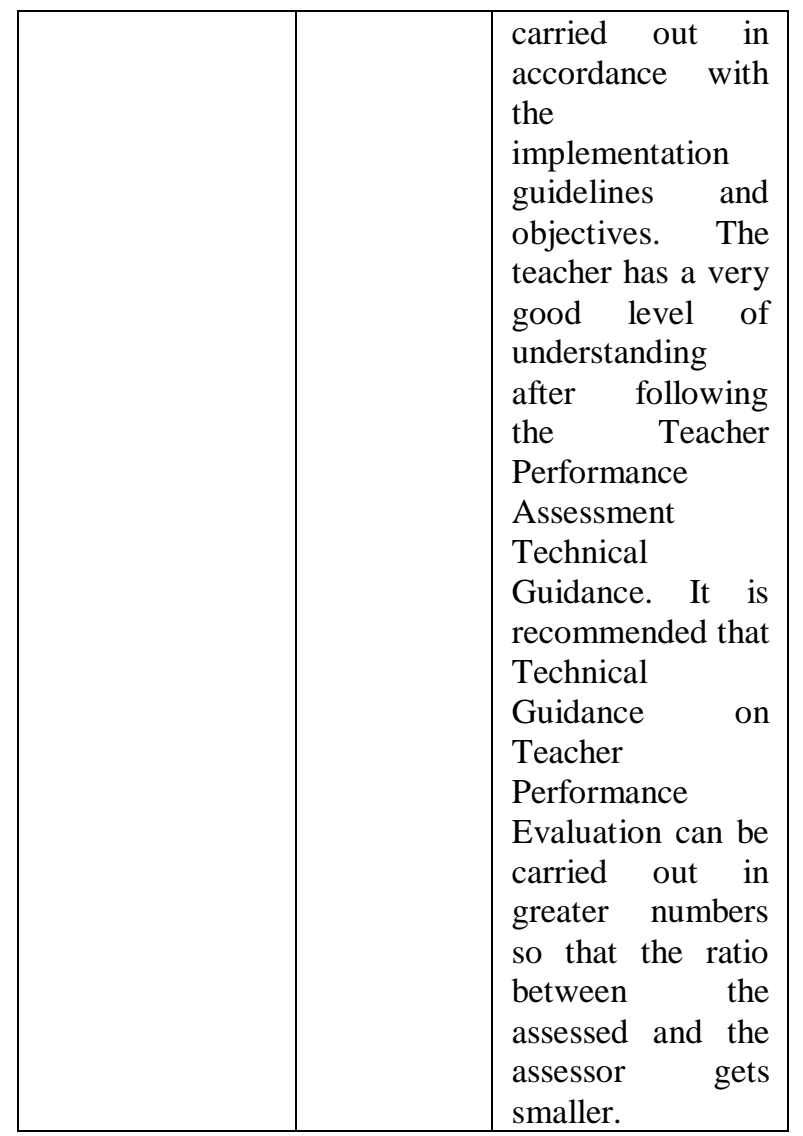

\section{PEMBAHASAN}

Pada era revolusi industri 4.0, dunia tidak lagi dipetakan menurut kekuatan ideologi sosial-politik suatu bangsa. Pemetaan dikotomik sudah mengalami perubahan berdasarkan kekuatan teknologi, salah satunya dibidang kecerdasan buatan. Dampak dari perubahan tersebut, menghasilkan pola interaksi yang serba cepat, produksi berbasis teknologi informasi lebih efesien, pemenuhan kebutuhan hidup lebih praktis dan mobilitas sosial penduduk dunia bersifat masif.

Dalam konteks ini, sebagaimana dalam laporan The Future of Jobs Report, World Economic Forum 2018 menyatakan bahwa kehidupan di era industri 4.0 menuntut seseorang untuk menguasai berbagai keterampilan SDM seperti complex problem solving, social skill, process skill, system skill, dan cognitive abilities (https://www.weforum.org). Upaya pencapaian keterampilan tersebut dapat dilakukan dengan pelaksanaan proses pendidikan yang berkualitas dan beroriensi pada mutu output hasil asessement berbasis literasi-numerasi.
Berdasarkan pada kondisi diatas maka dibutuhkan upaya penyelesaian melalui program pengembangan kompetensi guru secara berkelanjutan, karena guru memiliki peran startegis dalam proses pendidikan, meliputi kemampuan dalam manajemen pembelajaran dan melaksanakan sistem asessement berbasis literasi-numerasi.

Terkait dengan hal itu, beberapa hasil penelitian pada artikel diatas dikatakan bahwa pengembangan kompetensi guru melalui pembinaan terfokus dapat meningkatkan kemampuan guru dalam melaksanakan penilaian (Susanti, 29018). Sedangkan, Edy Supriyadi (2012) mengatakan untuk memenuhi kebutuhan pengembangan mutu sekolah diperlukan kompetensi guru dalam penilaian secara memadai yang dapat dilakukan melalui permberdayaan MGMP, praktik pengembangan berbasis best practices dan mengikutsertakan guru dalam berbagai training.

$$
\text { Selanjutnya Ernawati }
$$
menyatakan kompetensi guru dalam mengembangkan rubrik penilaian dapat ditingkatkan melalui pembinaan terstruktur secara konsisten. Ratna Hayati (2019) 
mengemukan guru diharapkan dapat meningkatkan kompetensinya dalam menyusun penilaian, agar pelaksanaan evaluasi dapat terlaksana dengan baik dan dapat mengukur kemampuan siswa dengan tepat sesuai dengan kebutuhan.

Slameto (2017) menyimpulkan dalam penelitiannya melalui program pengembangan dan pelatihan yang sistematis dapat meningkatkan kemampuan guru dalam melakukan perencanaan, pelaksaan dan evalausi assessment.

Pada penelitian-penelitian tersebut memiliki kelebihan dalam penekanan fokus kajian yakni pada masalah pengembangan kompetensi dalam asessement. Namun, juga terdapat kelemahan yakni pada kajian pengembangan kompetensi dalam asessement yang terfokus pada masalah lietrasi-numerasi, yang saat sedang menjadi kebutuhan di era industry 4.0. Oleh karena itu, pengembangan kompetensi guru dalam pelaksanaan asessement berbasis literasi-numerasi menjadi hal penting.

Beberapa hasil penelitian tentang kemampuan guru dalam asessement berbasis literasi-numerasi menunjukkan afirmasi bahwa upaya tersebut sangat dibutuhkan untuk pengembangan kompetensi peserta didik terlebih dalam perubahan di era industry 4.0 .

Anouke Bakx, dkk (2014) mengemukakan melalui evaluasi dan penilaian kompetensi secara terukur dapat membantu pengembangan profesionalisme guru. Alan Peacock dan Bill Rawson (2001) menyatakan model pengembangan kompetensi guru berkelanjutan berdasarkan pemberdayaan dan keterlibatan kolaboratif ditinjau dapat mendorong pengembangan kompetensi secara mandiri dalam pembelajaran dan penilaian.

Iris Vansteelandt, dkk (2020) mengemukan program pengembangan komptensi berkelanjutan (PKB) guru yang berorientasi pada kemampuan membaca dan motivasi membaca guru penting dipraktikan untuk menciptakan pembelajaran promotif bidang literasi siswa, baik pada aspek kemampuan maupun minat baca. Jasmin
Decristan, dkk (2019) menjelaskan bahwa bahwa kompetensi guru yang meliputi; pengetahuan konten pedagogis, literatif, efikasi diri, dan semangat mengajar berhubungan positif dengan minat siswa dan prestasi siswa dalam pembelajaran.

Viskovic, dkk (2017) mengemukakan bahwa kompetensi profesional dapat dikembangkan melalui pelatihan profesional, kegiatan lokakarya dan pendidikan pelatihan yang dirancang secara sistematis. Menggabungkan pengetahuan teoritis, contoh praktik yang berkualitas, dan diskusi untuk meningkatkan kompetensi guru profesional.

Sedangkan dalam konteks penggunaan model evaluasi yang digunakan untuk menegetahui efektitas pelaksanaan program pengembangan, secara umum hasil kajian penelitian mendeskripsikan kelebihan dan kelemahan model evaluasi tersebut.

Pada pelaksananan evaluasi program M. Hurmaini, dkk (2015), melakukan penelitian evaluasi dengan pendekatan model Konteks, Input, Proses dan Produk (CIPP), menghasilkan empat kesimpulan yang mendalam dan menyeluruh tentang program training. Tahapan-tahap program training dapat diuraikan dan dipahami secara mendalam melalui pendekatan CIPP. Kebutuhan, target dan rekomendasi dapat diperoleh deskripsinya secara sistematis.

Shamsa Aziz, dkk (2018) melakukan penelitiaan studi kasus dengan penerapan Model CIPP untuk mengevaluasi kualitas program di sekolah Level, menunjukkan hasil penelitian yang seimbang antara paparan deskripsi data secara faktual dan lengkap dengan rekomendasi pada titik kelemahan untuk perbaikan mutu program.

Secara metodologi, model CIPP dalam penelitian tersebut lebih menekankan pada peran sumatif, hasil dari model CIPP digunakan untuk menentukan apakah suatu program harus diganti, direvisi atau dipertahankan. Keputusan-keputusan evaluatif berbentuk keputusan sumatif, meskipun pada bagian tertentu juga memperhatikan keputusan formatif.

Kelemahan model ini terutama keterbatasannya pada fokus kajian secara 
komprehensif dalam proses evaluasi dan tidak adanya komponen pengembangan program melalui pelatihan, karena penekannya pada aspek produk. Oleh karena itu, penggabungan dari model evaluasi CIPP dengan model evaluasi Kirkpatrick perlu dilakukan.

Model evaluasi yang dikembangkan oleh Kirkpatrick dikenal dengan istilah Kirkpatrick Four Levels Evaluation Model dalam kajian penelitian menunjukkan kesimpulan bahwa model ini mampu memberikan indikator ketercapaian pelaksnaan program yang sesuai dengan kebutuhan. Dalam implementasinya model evaluasi terhadap efektivitas program pelatihan (training) mencakup empat level evaluasi, yaitu: level 1 reaction, level 2 learning, level 3 behavior, dan level 4 result.

Evaluasi terhadap reaksi peserta pelatihan/program berarti mengukur kepuasan peserta (customer satisfaction). Program pelatihan dianggap efektif apabila proses pelatihan dirasa menyenangkan dan memuaskan bagi peserta pelatihan sehingga mereka tertarik termotivasi untuk belajar dan berlatih. Dengan kata lain peserta pelatihan akan termotivasi apabila proses pelatihan berjalan secara memuaskan bagi peserta yang pada akhirnya akan memunculkan reaksi dari peserta yang menyenangkan. Sebaliknya apabila peserta tidak merasa puas terhadap proses pelatihan yang diikutinya maka mereka tidak akan termotivasi untuk mengikuti pelatihan lebih lanjut.

Kriteria keberhasilan pada evaluasi level ke 3 adalah perubahan sikap yang telah terjadi setelah mengikuti pelatihan akan diimplementasikan setelah mahasiswa mengikuti perkuliahan, sehingga penilaian tingkah laku ini lebih bersifat eksternal. Evaluasi hasil dalam level ke 4 ini difokuskan pada hasil akhir yang terjadi karena peserta telah mengikuti suatu program.

\section{KESIMPULAN DAN SARAN}

Pengembangan kompetensi guru berbasis kebutuhan merupakan kebutuhan skala prioriras bagi sekolah dalam peningkatan mutu ouput pendidikan.
Pengembangan kompetensi guru perlu dilakukan perencanaan dan asessement berbasis kebutuhan. Sesuai dengan perubahan dan kebutuhan peningkatan kualitas sumber daya manusia di era industry 4.0, pengembangan kompetensi guru difokuskan pada peningkatan kemampuan guru dalam pelaksanaan asessement berbasis literasinumerasi. Melalui program pengembangan dan pelatihan berbasis kebutuhan dalam kemampuan asessement diyakini dapat meningkatkan kemampuan guru dalam pelaksaaan asessement dan memperbaiki mutu output hasil pembelajaran peserta didik.

Upaya untuk mengetahui efektifitas dan dampak nyata dari pelaksanaan program pengembangan kompetensi guru berbasis kebutuhan dilakukan penelitian evaluasi dengan pendekatan mixed model yakni CIPP dan Kickpatrick (CILAPP). Melalui penerapan mixed model CILAPP akan didapatkan gambaran konteks penelitian evaluasi program yang utuh dan saling melengkapi. Proses pelaksanaan orang juga akan bersifat dinamis sesuai dengan kebutuhan dan penguatan program dalam bentuk pemberian treatment pelataihan.

Komposisi model dan desain evaluasi tersebut adalah CIPP (context, input, process, product) dan model Kirkpatrick, yang terdiri dari empat level dalam penelitian evaluasi; level 1 reaction, level 2 learning, level 3 behavior, dan level 4 result.

\section{DAFTAR PUSTAKA}

Agung Prihantoro. 2012. Peningkatan Kinerja Sumber Daya Manusia melalui Motivasi, Disiplin, Lingkungan Kerja, dan Komitmen. STIE Agama Islam Mathali'ul Falah

Anouke Bakx, dkk. Development and evaluation of a summative assessment program for senior teacher competence. Artikel dalam jurnal Studies in Educational Evaluation Volume 40, March 2014, Pages 50-62

Arikunto, Suharsimi (2009). Evaluasi Program Pendidikan: Pedoman Teoretis Praktis bagi Mahasiswa dan 
Praktisi Pendidikan. Edisi Kedua. Jakarta: PT. Bumi Aksara.

Astuti, S., Slameto, S., \& Dwikurnaningsih, Y. Peningkatan Kemampuan Guru Sekolah Dasar dalam Penyusunan Instrumen Ranah Sikap Melalui In House Training. Jurnal Manajemen Pendidikan, 4(1), 37-47. https://doi.org/https://doi.org/10.242 46/j.jk.

Aziz, Shamsa., Mahmood, Munazza., Rehman, Zahra. (2018). Implementation of CIPP Model for Quality Evaluation at School Level: A Case Study. Journal of Education and Educational Developement

Bill Rawson. Helping teachers to develop competence criteria for evaluating their professional development. International Journal of Educational Development Volume 21, Issue 2, January 2001, Pages 79-92

Brinkerhoff, Robert O. et al. 1986. Program Evaluation: A Practitioner's Guide for Trainers and Educationer, fourth edition. Boston: Keluwer Nijboff, Publishing

Cheryl N.Poth MichelleSearle Alexandra M.Aquilina JennyGe AlexaElder. Assessing competency-based evaluation course impacts: A mixed methods case study. Jurnal Evaluation and Program Planning Volume 79, April 2020, 101789

Djaali, Mulyono Puji dan Ramly. 2002. Pengukuran Dalam Bidang Pendidikan. Jakarta: PPs UNJ

Edy Supriyadi. (2018) Kompetensi Guru Dalam Penilaian Hasil Belajar SMK Bertaraf Internasional Jurnal Pendidikan Teknik Elektro FT UNY

Ernawati (2012). Peningkatan Kompetensi Guru dalam Menyusun Rubrik Penilaian Melalui Pembinaan Terstruktur (Penelitian Tindakan di SDN 1 Cempaka Lampung Utara). Jurnal Pedagogia | ISSN Online : 2715-6125

Hurmaini, M.; Abdillah. Evaluation on Social Internship Program of Iain Sultan
Thaha Saifuddin Jambi Students: Using Context, Input, Process and Product Model (CIPP Model) Journal of Education and Practice, v6 n11 p56-62 2015

https://www.weforum.org/reports/the-futureof-jobs-report-2018

https://hasilun.puspendik.kemdikbud.go.id/\#2 019 !sma!.

https://www.kemdikbud.go.id/main/blog/2019 /12/hasil-pisa-indonesia

.https://www.weforum.org

https://raharja.ac.id/2020/10/13/literaturereview/

Iris, Vansteelandt, Suzanne E.Mol, RubenVanderlinde, HildeVan Keer. 2020. In pursuit of beginning teachers' competence in promoting reading motivation: A mixedmethods study into the impact of a continuing professional development program. Teaching and Teacher Education Journal Volume 96, November 2020, 103154

Jasmin Decristan Anna, et.all. 2019. The effects of teacher competence on student outcomes in elementary science education: The mediating role of teaching quality. Teaching and Teacher Education Journal Volume 86, November 2019, 102882

Jauharul Islam, Ana., Soeaidy., Saleh, Hayat, Ainul. 2017. Evaluasi Dampak Peningkatan Mutu Pendidikan Dasar (Studi Tentang Program Desentralized Basic Education 2 (DBE2) di Kabupaten Nganjuk). Jurnal Administrasi Publik (JAP), Vol. 1, No. 6, Hal. 1096-1105

Kaufman, Roger. and Susan Thoma. 1980. Evaluation Without Fear, London

Kirkpatrick, D. L. (1998). Evaluating Training Programs: The Four Levels. San Francisco: BerrettKoehler Publisher, Inc.

Stufflebeam, Daniel L., dan Antony J. Shienkfield. (1985). Systemati Evaluation. Boston: Kluwer-Nijhoff Publihing. 
Susianti. (2018). Upaya Meningkatkan Kompetensi Guru dalam Melaksanakan Penilaian Kurikulum 2013 melalui Bimbingan Terstruktur di MIN 2 Gunungkidul. Jurnal Pendidikan Madrasah, Volume 3, Nomor 1, Mei 2018 P-ISSN: 25274287 - E-ISSN: 2527-6794

Viskovic, Ivana; Višnjic Jevtic, Adrijana. Development of Professional Teacher Competences for Cooperation with Parents.. Artikel dalam Jurnal Early Child Development and Care, v187 n10 p1569-1582 2017

World Bank. 2020. Janji Pendidikan di Indonesia.C World BanK

Wukir. 2012. Manajemen Sumber Daya Manusia Dalam Organisasi Sekolah. Yogyakarta: Multi Pressindo. 